\title{
The Empirical Study on Factors Influencing Consumer Trust in Online Trading
}

\author{
Huang Jinhong \\ Wuhan Technology and Business University \\ Wuhan, China \\ e-mail: 30157704@qq.com \\ Wan Hui \\ Wuhan Technology and Business University \\ Wuhan, China \\ e-mail: 108181539@qq.com
}

\author{
Xu Wei \\ Wuhan Technology and Business University \\ Wuhan, China \\ e-mail: 16661021@qq.com \\ Wei Hua \\ Wuhan Technology and Business University \\ Wuhan, China \\ e-mail: 344166747@qq.com
}

\begin{abstract}
In China e-commerce is developing rapidly, but the lack of trust becomes the main obstacle to consumer intention in online trading. This paper summarized seven factors affecting the online trading trust level firstly, and made some scientific hypotheses. Then it examined the influence of seven factors such as personal trust tendency, trading platform, communication between the seller and the buyer, payment service, feedback system, trading turnover, and laws on consumer trust in online trading. In this paper, the questionnaire data used the factor analysis method, the results showed that among the factors affecting the consumer online trust level, in addition to the "third party payment service", "trust of transaction objects", "laws and regulations", "trading turnover", "personal propensity to trust", "trading platforms" and other factors all had a significant influence on consumer trust in online transactions. Finally, it gave some suggestions about increasing consumer trust in online trading. This paper is intending to be able to make progress on the progress of building consumer online trust.
\end{abstract}

Keywords- consumer; online trading; trust; influencing factors; factor analysis method

\section{INTRODUCTION}

In 2013 China's e-commerce transaction scale has reached up to 9.9 trillion Yuan, which was $21.3 \%$ year-onyear growth. The scale of network shopping market business reached 1.85 trillion Yuan, increased by $42.0 \%$. The online shopping turnover accounted for the proportion of total retail sales of social consumer goods was $7.8 \%$, increased by $1.6 \%$ compared with $2012^{[1]}$.

However, the online sales compared to the offline are still very limited both at home and abroad. Because online transactions have open and anonymous characteristics and confront big risk, people do not use the online shopping mainly because of distrust of the online shopping environment. Analysis of the factors influencing consumer trust in online trading has a strong practical significance.

\section{TRUST THEORY}

Mayer and some others put forward that, trust is one willing to give up the right to monitor and control the other party, which makes the weakness of itself exposes and the other party may harm its rights and interests, and it is also a kind of determination of believing that the other party will not take advantage of its weaknesses. In e-commerce activities, trust of the trading object and the network media constitute the consumer trust in online trading. ${ }^{[2]}$

Many factors affect the online trading trust. Sultan and other people think website features such as: browse, correctness, advice, privacy/security, logo, trust mark and brand are factors influencing trust. While Jafvellpaa et al got the conclusion that the consumer online trust is related to the size of the online store and the credibility. Hoffman and others confirmed that the dominant factors affecting online trust is security and privacy through studies. ${ }^{[3]}$

To conclude the conclusions of predecessors, this paper summarizes seven factors affecting the online trading trust level. It will examine the influence of seven factors such as personal trust tendency, trading platform, law, etc. on consumer trust in online trading.

\section{PROPOSED HYPOTHESIS}

\section{A. Personal trust tendency}

Personal trust tendency points to the extent of the personal willingness to trust others or other things and it is the individual tendency of attitude to trust others. Some people will choose to believe in things the ordinary people basically don't believe. On the contrary, although some things have a lot of evidence to prove that it can be believed, but some people still choose not to believe. ${ }^{[4]}$ Under the condition of similar risk and risk-prefer consumers are more willing to trade on the Internet than risk-averse consumers.

Hypothesis 1: consumer's personal trust tendency affects the online trading trust level.

\section{B. Recognition of the trading platform}

E-commerce platform is divided into B2C, B2B, C2C, etc. For individual consumers, their online trading is likely to give priority to $\mathrm{B} 2 \mathrm{C}$ platform, secondly to consider the high-profile $\mathrm{C} 2 \mathrm{C}$ platform, in order to ensure their rights and interests can be realized. ${ }^{[5]} \mathrm{B} 2 \mathrm{C}$ platform is also more likely to take standardize management, once consumers' 
rights and interests are infringed, it is more easy to blame the corporate than the individual.

Hypothesis 2: recognition level of trading platform will determine the consumer trust level of online trading.

\section{Communication between the seller and the buyer}

Communication between the buyer and seller is a very important link in the entire network trading. In the pre-sale, if the seller can quickly respond to customer problems and solve the customer's doubts, provide personalized products or services, and then the customer will quickly be attracted to the seller. In the after-sale, if the seller can send consumers small gifts, coupons, etc., timely and courteously explain objective reasons to the customer when consumer is in dissatisfaction, or quickly arrange changing or refunding for the customer, the consumer will also have a favor to the seller, which will make the sense of trust deeper. ${ }^{[6]}$

Hypothesis 3: the depth of the communication between the seller and the buyer will determine the consumer online trading trust level.

\section{The payment service of the third party}

There is a paradox existing in online shopping transactions: if the buyer makes the payment in advance then one will concern about dissatisfaction to the goods that will be delivered or even simply no arrival of the goods; if the seller makes the shipment in advance, then one will concern about the buyer not to pay. Thus payment security is particularly important, therefore, to solve this problem, the platform introduced a third-party payment service, the service increased the consumer online trading trust level.

Hypothesis 4: the payment service of the third party can influence consumer online trading trust level.

\section{E. Reputation feedback system}

Reputation feedback system is a kind of credit evaluation mechanism, buyers and sellers evaluate each other after the deal was done on the basis of experience in the trading process. The better of the seller's reputation, usually the higher score it obtained in the reputation feedback system, the better the comments received. Through the seller's scores and comments and so on in reputation feedback system, the buyer can judge the seller's credit level more easily. ${ }^{[7]}$

Hypothesis 5: reputation feedback system will affect consumer online trading trust level.

\section{$F$. The trading turnover}

The turnover of the merchandise refers to the quantity of an item successfully traded within a unit of time between the buyer and the seller. Consumers tend to focus on the turnover first when shopping goods, because in general, high turnover accompanies higher credibility; while if the credit is high, the turnover is relatively better. Consumers will feel more secure in shopping because many people have already bought the goods.

Hypothesis 6: the volume of the turnover will affect consumer online trading trust level.

\section{$G$. The relevant laws and regulations of e-commerce}

The relevant laws and regulations of the e-commerce industry have certain constraints to reduce opportunistic behavior and enhance consumer trust. Consumers want to have complete e-commerce related laws and regulations and in the event of a dispute, they can provide legal basis for processing and solving the dispute, constraints of the laws and regulations may make consumers have more trust in online shopping.

Hypothesis 7: the laws and regulations relevant to ecommerce can influence consumer online trust level.

\section{RESEARCH METHODS AND PROCESS}

This research adopted the online electronic questionnaire survey method to obtain data. The questionnaire contains seven factors and a total of 20 indicators. Then used SPSS software to analyze the data and validated the above seven assumptions. The questionnaire survey got 107 effective questionnaires.

\section{A. The statistical analysis of the basic characteristics of sample population}

TABLE I. STATISTICAL CHARACTERISTICS OF SAMPLE POPULATION SURVEYED

\begin{tabular}{|c|c|c|c|}
\hline Category & Option & $\begin{array}{c}\text { Sample } \\
\text { quantity }\end{array}$ & Percentage \\
\hline \multirow{2}{*}{ Sex } & male & 49 & $45.8 \%$ \\
\hline & female & 58 & $54.2 \%$ \\
\hline \multirow{5}{*}{ Age } & $\begin{array}{lll}\begin{array}{l}\text { Below } \\
\text { old }\end{array} & 18 & \text { years } \\
\end{array}$ & 3 & $2.8 \%$ \\
\hline & $18-22$ years old & 50 & $46.7 \%$ \\
\hline & $23-29$ years old & 39 & $36.5 \%$ \\
\hline & $30-39$ years old & 12 & $11.2 \%$ \\
\hline & $\begin{array}{lll}\text { Above } 40 & \text { years } \\
\text { old }\end{array}$ & 3 & $2.8 \%$ \\
\hline \multirow{4}{*}{$\begin{array}{l}\text { Education } \\
\text { background }\end{array}$} & undergraduate & 74 & $69.2 \%$ \\
\hline & master & 9 & $8.4 \%$ \\
\hline & doctor & 1 & $0.9 \%$ \\
\hline & others & 23 & $21.5 \%$ \\
\hline \multirow{4}{*}{ Occupation } & student & 70 & $65.4 \%$ \\
\hline & office worker & 21 & $19.7 \%$ \\
\hline & freelance & 9 & $8.4 \%$ \\
\hline & others & 7 & $6.5 \%$ \\
\hline \multirow{5}{*}{ Online age } & less than a year & 2 & $1.8 \%$ \\
\hline & $1-2$ years & 5 & $4.6 \%$ \\
\hline & $2-3$ years & 15 & $14.0 \%$ \\
\hline & 3-5 years & 37 & $34.8 \%$ \\
\hline & Over 5 years & 48 & $44.8 \%$ \\
\hline
\end{tabular}

From table I, it can be concluded that the surveyed object has the following obvious characteristics: online shopping female are more than male slightly; give priority to young Internet users; most online shoppers have a relatively high degree; most of respondents have certain network use history.

\section{B. Reliability and validity analysis}

\section{1) analysis of reliability}

Reliability refers to the stability and the internal consistency of the measured results worked out by the measurement tools ${ }^{[8]}$. Cronbach consistency coefficient (Cronbach alpha) was used to examine the scale's reliability. Through the operation of the SPSS, the reliability coefficient of each factor in the questionnaire was calculated. Table II shows that all the Cronbach $\alpha$ of the seven factors were greater than 0.60. Therefore, this questionnaire has good reliability. 
TABLE II. TABLE OF RELIABILITY COEFFICIENT OF EACH FACTOR IN THE QUESTIONNAIRE

\begin{tabular}{|l|c|c|c|}
\hline $\begin{array}{c}\text { Dimensionality } \\
\text { factor }\end{array}$ & $\begin{array}{c}\text { Indicator } \\
\text { quantity }\end{array}$ & $\begin{array}{c}\text { Serial number } \\
\text { in the } \\
\text { questionnaire }\end{array}$ & Cronbach $\boldsymbol{\alpha}$ \\
\hline $\begin{array}{l}\text { Personal trust } \\
\text { tendency }\end{array}$ & 3 & $1,2 、 3$ & 0.628 \\
\hline $\begin{array}{l}\text { Trading } \\
\text { platform }\end{array}$ & 3 & $4 、 5$ & 0.740 \\
\hline $\begin{array}{l}\text { Payment service } \\
\text { of third-party }\end{array}$ & 3 & $6 、 7 、 8$ & 0.819 \\
\hline $\begin{array}{l}\text { Communication } \\
\text { between the } \\
\text { seller and the } \\
\text { buyer }\end{array}$ & 3 & $9 、 10 、 11$ & 0.921 \\
\hline $\begin{array}{l}\text { Reputation } \\
\text { feedback system }\end{array}$ & 3 & $12 、 13,14$ & 0.868 \\
\hline $\begin{array}{l}\text { Trading } \\
\text { turnover }\end{array}$ & 3 & $15 、 16 、 17$ & 0.870 \\
\hline $\begin{array}{l}\text { Laws and } \\
\text { regulations }\end{array}$ & 3 & $18 、 19,20$ & 0.669 \\
\hline
\end{tabular}

2) analysis of validity

Validity refers to the proximity between the measurement results and the target trying to achieve, the bias and systematic error are evaluated to test the accuracy of the scale content. To measure KMO in the first place, when the value of KMO is lower than 0.5 , it is not suitable for factor analysis. ${ }^{[9]}$

Seven factors were conducted KMO test analysis and the results are shown in table III. $\mathrm{KMO}=0.802>0.500$, which indicates that it is suitable for factor analysis.

TABLE III. TEST RESUltS OF KMO AND BARTLETT

\begin{tabular}{|c|l|}
\hline $\begin{array}{l}\text { Take the sample of enough Kaiser-Meyeer-Olkin for } \\
\text { measurement. }\end{array}$ & 802 \\
\hline Degree of sphericity of Bartlett similar to chi-square & 672.574 \\
\hline dr & 190 \\
\hline Sig. & 000 \\
\hline
\end{tabular}

\section{3) factor analysis}

Principal component analysis (pca) was used to extract factors with eigenvalues greater than 1. As shown in Fig .1, the variance of the overall explanation, finally five factors were got through dimension reduction, and explained $67.112 \%$ of the variance totally.

\begin{tabular}{|c|c|c|c|c|c|c|c|c|c|}
\hline \multicolumn{10}{|c|}{ The total variance of the explatation } \\
\hline No. & Initi & eigenva & & Extract & $\begin{array}{l}\text { sum of } \\
\text { loaded }\end{array}$ & quares & Rotate & $\begin{array}{l}\text { I sum of } \mathrm{s} \\
\text { loaded }\end{array}$ & quares \\
\hline ב3: & 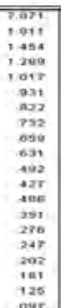 & 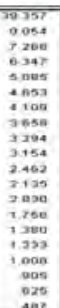 & 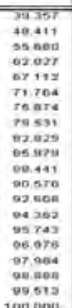 & 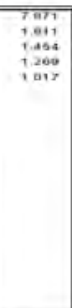 & 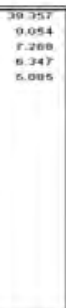 & 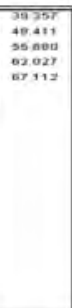 & 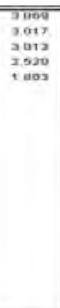 & 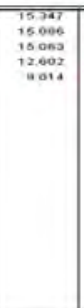 & 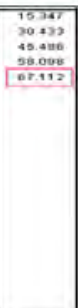 \\
\hline
\end{tabular}

Figure 1. The Total Variance of the Explanation

Varimax rotated principal component analysis results, as shown in Fig .2, precipitated into five factors, in addition to the "third party payment service" and "reputation feedback system" were not precipitated into two independent factors in accordance with the expected before, the rest factors were all precipitated as expected.

\begin{tabular}{|c|c|c|c|c|c|}
\hline \multicolumn{6}{|c|}{ Component Rotated component matrix } \\
\hline \multirow{21}{*}{ 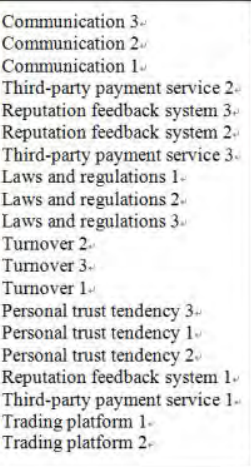 } & & 2 & Compo & & \\
\hline & 719 & 065 & .140 & wo & .116 \\
\hline & 691 & 173 & 270 & 186 & -.011 \\
\hline & .657 & 184 & 150 & -.001 & 271 \\
\hline & .554 & .333 & -165 & .120 & 268 \\
\hline & .546 & 189 & 323 & .010 & .451 \\
\hline & 473 & 397 & .351 & 401 & .164 \\
\hline & 256 & 785 & 161 & 149 & 115 \\
\hline & .077 & 757 & .064 & 218 & -.023 \\
\hline & .460 & 670 & .282 & 157 & .047 \\
\hline & 181 & 560 & .387 & .407 & 111 \\
\hline & .031 & 288 & .852 & .094 & .166 \\
\hline & 231 & -.079 & .806 & .014 & \\
\hline & 247 & .445 & 647 & 192 & 108 \\
\hline & .161 & 205 & .583 & .436 & .136 \\
\hline & -.070 & 177 & .033 & .777 & .146 \\
\hline & .092 & 218 & .162 & .622 & .050 \\
\hline & 517 & 037 & .058 & .579 & -.181 \\
\hline & .037 & 373 & .084 & .006 & 751 \\
\hline & .229 & -.276 & 110 & 091 & .634 \\
\hline & .330 & .064 & .334 & 280 & 529 \\
\hline
\end{tabular}

Figure 2. The Rotated Factor Loading Matrix

The author thinks that this is because "reputation feedback system" and "communication between the seller and the buyer" both indicators are the factors related to the "seller", so consumer perception of the situation is very similar, so " communication between the seller and the buyer" and "reputation feedback system" two indicators can be combined into "confidence in the transaction object. As for why the "third party payment service" wasn't precipitated as expected, given that the consumer can choose to "cash on delivery" payment, consumers do not necessarily have to rely on third-party payment service.

\section{CONCLUSIONS AND SUGGESTIONS}

\section{A. Conclusions}

Fig .1 shows that there are five factors of the seven factors in the investigation having a significant influence on consumer online trust. Fig .2 can conclude that only each factor rotation results of the main factor "payment service of third-party" dispersed, so this main factor "payment service of third-party" has no significant influence on consumer online trust. Therefore, this study finally gets the conclusion as follows:

1) Consumers' personal trust tendencies affect the online trading trust level, namely hypothesis 1 was established.

2) Consumer acceptance of the trading platform will determine its online trading trust level, namely hypothesis 2 was established.

3) In data analysis it was found that incorporating reputation feedback system and the communication between the seller and the buyer is suitable for the trust of the objects of the deal. At the same time it also confirmed that the consumer's trust in the transaction object will determine its online trading trust level. So the hypotheses 3 and hypotheses 5 were established.

4) The trading turnover will affect consumer online trust level, that is to say the hypothesis 6 was established.

5) The perfection and standardization degree of $e$ commerce related laws and regulations will affect consumer online trading trust level, the hypothesis 7 was established. 
6) Consumers can choose to "cash on delivery" payment, do not necessarily have to rely on "third-party payment service", so the hypothesis 4 failed.

\section{B. Suggestions about increasing consumer trust in online trading}

China's online shopping market is booming. At present, how to grasp the consumer psychology, effectively enhance the consumer trust level, make potential customers into real customers and maintain long-term loyalty, become the targets of each e-businessman. Based on the above research, following suggestions are made with hope to have certain guiding significance.

1) Keep promise, create a good brand image

This article through analysis proves that the consumer trust intention and trading platform have very big relations, superior brand image of the trading platform shows that the credible degree of the platform is higher, it is more easy to form the customer brand loyalty. So, the website operators should pay attention to the following two points: integrity is the foundation of the business, in the virtual world, keeping promise is also in need, and avoiding fraudulent conducts. To strengthen the construction of brand, the brand can bring more security and comfort to consumers, to gain trust of consumers.

2) The sellers should pay attention to the communication with the customers

The importance of the sellers' service attitude to the purchase intention of the buyers in the reality is selfevident, even in virtual network world, its impact on the buyers' trust intentions is very great. The communication between the buyers and the sellers is a way for the buyers to understand the sellers' products and services, and also the channel of deepening the understanding between the sellers and the buyers, and the process of the buyers' trust increasing to the sellers as well.

3) The government should strengthen the construction of legal system in electronic commerce

Although this study shows that e-commerce related laws and regulations have an effect on the online trading trust level, but the effect is not very clear. This is because the current laws and regulations about the specification of e-commerce industry of our country are not perfect, so it is difficult to have a significant effect on consumer trust. Our country should strengthen the construction of legal system in the field of electronic commerce, provide legal basis for both trading parties when dispute occurs.

\section{RESEARCH LIMITATIONS AND PROSPECTS}

Due to the limitation of various factors, this study also has some limitations: first, the study did not distinguish the consumer online consumption types, such as: for goods with different unit price, consumer behavior may be different. Second, due to the short of time, the number of influencing factors investigated is less, and there were no distinction of consumers of different age and sex.

Research can attempt to classify consumers shopping different types of goods ${ }^{10]}$, for example, may be considered to divide into types of: clothing, digital products, cosmetics, style items, house ware and virtual items, etc; detailed research on different consumers can be conducted according to population characteristics.

\section{REFERENCES}

[1] Iresearch Consulting Group. Brief version of 2012-2013 Annual Monitoring Report of China's e-commerce industry [R]. Iresearch, October 2013, pp.2-3.

[2] Xu Shengnan. E-commerce Trust Mechanism Study [J]. Modern Commercial and Trade Industry, January 2013, pp.26-28.

[3] Tian Jian, CAI Jun. Research of the Influential Factors of Consumer Trust in Network Group Purchase [J]. China Journal of Information Systems, December 2013, pp.34-37.

[4] Chen Liying. The Empirical Research of Factors Affecting Consumer Purchase Intention on B2C Shopping Websites [D]. Guangxi University, June 2011, pp.12-13.

[5] Xiao A'ni, Han Yuwei. The Empirical Analysis of the Factors Influencing Consumer Online Trust in $\mathrm{C} 2 \mathrm{C}$ E-commerce [J]. Journal of Guangxi College of Finance and Economics, March 2011, pp.75-78.

[6] Cai Jun. The Influential Factors of Consumer Trust in Network Group Purchase and The Empirical Research [D]. Jiangsu University of Science and Technology, December 2013, pp.5-7.

[7] Guan Rongwei. Trust Influencing Factors Analysis of Online Sellers Based on Consumer Awareness [J]. Journal of Enterprise Economy, October 2013, pp.114-116.

[8] Dong Wei. SPSS Statistical Analysis Advanced Course [M]. Higher Education Press, December 2009, pp.33-45.

[9] Wu Minglong. SPSS Statistical Application Practice: Questionnaire Analysis and Application Statistics [M]. Chongqing University Press, May 2010, pp.77-97.

[10] Yang Qian, Liu Yi, Han Zhao. Research on Customer Trust Influencing Mechanism in Online Shopping [J]. Journal of Information. May 2011, pp.84-87. 